Esta publicación cientifica en formato digital es continuidad de la revista impresa ISSN-Versión Impresa 0798-1406 / ISSN-Versión on line 2542-3185Depósito legal pp
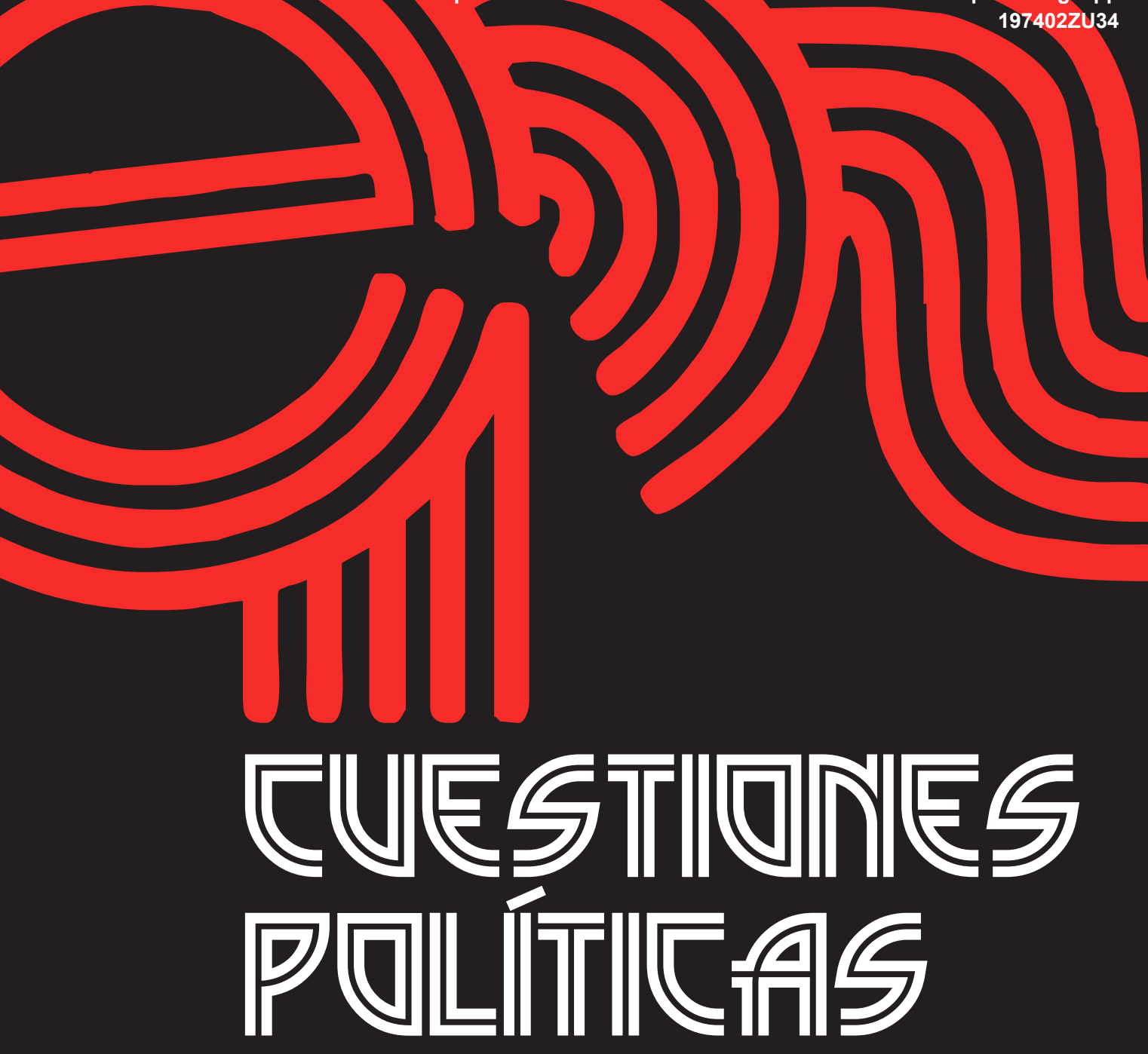

Instituto de Estudios Políticos y Derecho Público "Dr. Humberto J. La Roche" de la Facultad de Ciencias Jurídicas y Políticas de la Universidad del Zulia Maracaibo, Venezuela
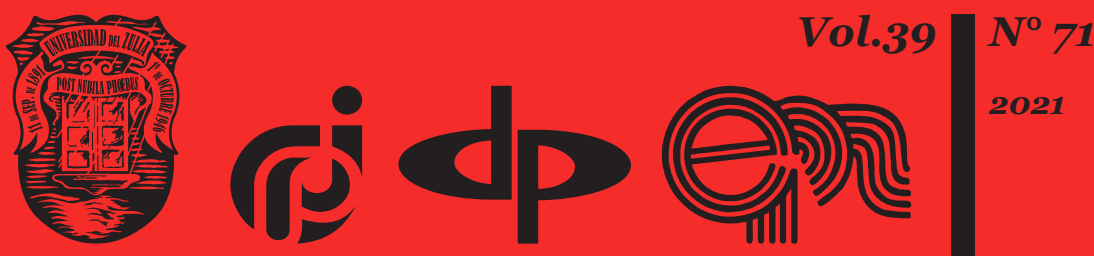


\title{
American constitutionalism and the mid-19th-century nation
}

\author{
DOI: https://doi.org/10.46398/cuestpol.3971.37
}

\author{
Roman Romashov * \\ Ekaterina Petrova ** \\ Zurab Kalandarishvili *** \\ Victor Kovalev ****
}

\begin{abstract}
The authors of the article have studied the causes of the American Civil War with due regard to the history of constitutional law. This research is based on several political, economic, legal and cultural factors. The authors used the method of analyzing historical documents. After analyzing judicial precedents and global historical trends, they have concluded that America's constitutional institutes lost their effectiveness and became a weapon in the hands of struggling parties during the constitutional crisis. As a result, the compromise system of the early nineteenth century
\end{abstract} became a new state and legal structure.

Keywords: Causes of the Civil War; American constitutionalism; U.S. legal system; slavery in American history; legal-institutional history.

* Murmansk Arctic State University, Murmansk, Russia. ORCID ID: https://orcid.org/oooo-ooo19777-8625

** Ivanovo State University, Ivanovo, Russia. ORCID ID: https://orcid.org/oooo-0oo2-9149-3888

*** Saint-Petersburg University of Humanities and Social Sciences, Saint-Petersburg, Russia. ORCID ID: https://orcid.org/oooo-0002-8174-1809

***** Saint-Petersburg University of Humanities and Social Sciences, Saint-Petersburg, Russia. ORCID ID: https://orcid.org/oooo-0003-0040-5828 


\section{El constitucionalismo estadounidense y la nación de mediados del siglo XIX}

\section{Resumen}

Los autores del artículo han estudiado las causas de la Guerra Civil estadounidense teniendo debidamente en cuenta la historia del derecho constitucional. Esta investigación se basa en varios factores políticos, económicos, legales y culturales. Los autores utilizaron el método de análisis de documentos históricos. Tras analizar los precedentes judiciales y las tendencias históricas mundiales, han concluido que los institutos constitucionales de Estados Unidos perdieron su eficacia y se convirtieron en un arma en manos de los partidos en lucha durante la crisis constitucional. Como resultado, el sistema de compromisos de principios del siglo XIX se convirtió en una nueva estructura estatal y legal.

Palabras clave: Causas de la Guerra Civil; Constitucionalismo estadounidense; Sistema legal de Estados Unidos; esclavitud en la historia de Estados Unidos; historia jurídico-institucional.

\section{Problem statement: citizenship and rights at the federal and state levels}

American constitutionalism in the late $18^{\text {th }}$ and early 19 th centuries had several "pitfalls" that created zones of potential tension in the US political and legal field. Some problems arose at the very beginning of USA history and had been successfully masked by the system of compromises and figures of speech in the constitutional documents written by the Founding Fathers.

The first challenge was the lack of clarity about the rights of citizens in the United States and their guarantees. Therefore, there is a logical question: how does US citizenship correlate with the citizenship of each state and who is authorized to use the power of law to protect these rights, namely the state government or the federal government? Traditionally, states (Kettner, 1978) ensured civil rights, i.e., protected life, liberty, and property through their institutions, statutes, and court decisions, while punishing crimes and resolving civil disputes. Although states were the guarantors of rights, there was no clear theory of citizenship. In 1862, the Attorney General under President Lincoln admitted that he did not like the definition of "a citizen of the United States" and argued that "the matter was as obscure as it was at the moment the American state was founded" (Kaczorowski, 1986: 872).

The pre-Civil War legal theories generally accepted two types of rights: basic and inalienable rights guaranteed by the federal government and 
protected by federal courts, which could not be denied by states, and rights that did not need a national guarantee (Wiecek, 1977). Nevertheless, precedents important for the American constitutional theory demonstrated different views on this issue.

In Corfield v. Coryell (1823), Supreme Court Justice Bushrod Washington ruled that:

We felt no hesitation in confining these expressions to those privileges and immunities which are, in their nature, fundamental; which belong, of right, to the citizens of all free governments; and which have, at all times, been enjoyed by the citizens of the several states which compose this Union, from the time of their becoming free, independent, and sovereign (Hurd, 1968: 551).

At the same time, there are other rights approved by certain states and valid only in their territory.

However, not all court decisions supported this viewpoint. In Barron v. Baltimore, the Supreme Court claimed that the Fifth Amendment in particular and the Bill of Rights in general restricted the federal power and could not be considered as delegating to it any powers to protect the rights of citizens. The comity clause in Article 4 of the US Constitution empowers the federal government to guarantee the rights of citizens of one state if they are discriminated against in the territory of another. At the same time, the rights of citizens are protected exclusively by the authorities and courts of the state in question (Hurd, 1968).

Initially, state citizenship and US citizenship had been regarded as two aspects of the same status. Gradually, the primary loyalty and supremacy of guarantees had become questionable. This issue reached a new level and acquired an additional aspect since it dwelled on territorial structure, the balance of powers between the federal center and state authorities, and the implementation of the principle of subsidiarity. In its extreme form, this problem conditioned the right to secession.

Is the United States a community created by the united will of a political nation or a federation of sovereign and independent states? During the mid19th century crisis, two views became polarized. The proponents of unity headed by A. Lincoln argued that the Union and the nation preceded the Constitution, which logically follows from its Preamble: "We the People of the United States, in Order to form a more perfect Union..." (Kettner, 1978: 339). In mathematical terms, A. Lincoln understood the Union as a set, uniting several subsets, of which only the former could have the supremacy.

The secessionists represented the Union as an agent of independent states that delegated their sovereignty to the federal government. At the same time, citizens delegated their rights to the states, and the states further delegated their rights as collective entities rather than individual rights of citizens (Kettner, 1978). 
The important factors that stipulated the growth of constitutional confrontation were a growing gap in the economy and management of the North and the South, as well as the issue of slavery, which were closely connected.

\section{A system of compromises in a crisis. Political balance and judicial precedents}

The constitutional tradition required maintaining a balance between the Southern and Northern states in the Senate. Therefore, the admission of new states to the Union had to be in a 1:1 ratio. For example, the adoption of slave Missouri in 1820 was compensated by the division of Massachusetts into two states (Massachusetts and Maine). This system maintained a balance but was not formalized, which created the risk of complications. One possible way to overcome them was the Missouri Compromise, according to which states were divided into free and slave along the parallel $36^{\circ} 30^{\prime}$ north from the western tip of Missouri.

If the situation with California and Texas was more or less obvious since they were included in the Union as states with their own Constitutions and their inclusion kept the balance (Texas was a slave state, California was a free state), then the issue with territories was quite challenging (Carlisle, 2008).

The Northern states protested not against slavery but feared the expansion of the southerners' power. The latter suspected the northerners of conspiracies and tension between the parties increased. In 1846, Congressman David Wilmot of Pennsylvania proposed prohibiting slavery in any territory purchased or seized from Mexico (Wilmot Provisio). Alternatively, the Southern Democrats offered to extend the Missouri Compromise line to the Pacific Ocean. According to the southerners, it was unfair that the territories acquired due to joint efforts would become unequivocally free, i.e. would give a political advantage to the North.

As a result, Senator from Kentucky Henry Clay proposed a package of eight decisions that had far-reaching political and constitutional consequences. Some of them satisfied both parties, including the admission of Texas as a slave state and California as a free state, the federal government securing the debts of the Republic of Texas, the planning of Utah and New Mexico without resolving the issue of slavery (Carlisle, 2008). There was a comradely gesture towards the northern abolitionists, namely the prohibition of slavery in the Federal District of Columbia which created some inconvenience for the southern congressmen who could not bring their slaves. 
However, the following action brought the confrontation to a new level and emphasized the issue of human rights and the balance of powers between the states and the federal government (Varon, 2008). This referred to the Fugitive Slave Act of 1850.

In 1793, a law was passed that allowed masters to pursue fugitive slaves even in free states. However, the law did not oblige local authorities to facilitate slave owners and slave hunters who acted at their own risk. This law was followed by numerous precedents.

In Prigg v. Pennsylvania, the US Supreme Court considered the conflict between the federal act of 1793 and the Pennsylvania state law of 1826, according to which:

If any person or persons shall by force and violence take and carry away [...] any negro or mulatto from any part of that commonwealth, with a design and intention of selling and disposing of [...], every such person or persons be deemed guilty of a felony (Goldstein, 2011: 763).

Pennsylvania authorities arrested a runaway-slave hunter Edward Prigg and his four assistants who apprehended Margaret Morgan living in Pennsylvania as a free woman without her master's permission.

In the course of judicial proceedings, Prigg appealed to the US Supreme Court. Judge Joseph Story found the law of 1826 inconsistent with Article 4 of the US Constitution. However, he upheld the state's right to prohibit its officials from assisting in the capture of fugitive slaves since state officials reported to their state rather than the federal government (United States Supreme Court, 1842). This caused a range of new laws on personal freedom in the Northern states which prohibited filing and accepting claims for the return of fugitive slaves, considering cases and providing any assistance in the capture.

The Fugitive Slave Act required state governments to assist in the capture of fugitive slaves. Another concern for the supporters of freedom was an article according to which a judge deciding in favor of returning a slave to their owner received a remuneration of $\$ 10$ and a judge recognizing a black person free got only $\$ 5$. Opponents reasonably accused slave owners of bribing judges (Huston, 2003).

The Northern states objected that blacks have equal rights with white citizens. In 1842, there was great difficulty in adopting the Constitution of Rhode Island to expand the rights of the population, including giving black citizens of Rhode Island voting rights (Fitz 246). This was the victory of the Equal Rights Party building its election campaign on anti-slavery rhetoric. Under the Constitution of Rhode Island or the so-called "the people's constitution", blacks could bring claims to the court on an equal footing, including defending their freedom, and appeal to the Habeas Corpus Act. 
The other Northern states began enacting freedom laws that allowed blacks to defend their rights in court through various freedom suits.

Courts supported the above-mentioned theory and created several precedents. In 1852, the New York Supreme Court ruled in the case of Lemmon v. New York. The Lemmons, Virginia planters, decided to move to Texas. For reasons of economy and safety, they chose to travel by sea. They arrived in New York with eight slaves, including two children aged between five and two years old. In New York, there was a law passed in 1817, according to which any slave who found themselves in New York, even in transit, could file a claim for freedom (Fehrenbacher, 1997: 394).

During judicial proceedings, the Lemmons appealed to the fact that there was a transit trade between two states and each of them recognized slavery as legal. Under the courtesy clause, this trade was subject to federal regulation and states could not restrict it at their own discretion. The defense represented by John Jay (grandson of the first Chief Justice of the United States) and future President Chester Arthur claimed that the Lemmons deliberately and voluntarily brought slaves to New York, knowing that this was a free state. While requiring assistance in the return of fugitive slaves, the federal law neglected slaves who legally filed a claim for freedom. In this regard, an expansive interpretation of federal laws on civil rights and freedoms is unacceptable.

Judge Payne ruled that slavery could only be established by positive law based on the English precedent in the Somerset v. Stewart case of 1772 (Nadelhaft, 1966). Getting into the territory without such a law, slaves automatically became free. Such precedents as Winny v. Whitesides (1824) and Rachel v. Walker (1832) determined that "the one liberated, becomes forever free" and slaveowners could not claim the return of their property even if they moved to any slave state.

A similar decision was made in Holmes v. Ford in the Oregon Territory in 1853, which created a precedent for the regulation of slavery by the laws of not only states but also those of the federal territories (Lockley, 1922).

In Ableman v. Booth (1859), the US Supreme Court partially overturned this practice. In 1854, the abolitionist Sherman Booth was arrested for hindering US Marshal Stephen Ableman from capturing the fugitive slave Joshua Glover. However, Booth was released by a county judge in Wisconsin who found the federal agent's actions unconstitutional. Later this decision was approved by the Wisconsin Supreme Court. Ableman filed a complaint with the federal district court but the Wisconsin Supreme Court ruled that such decisions had no effect across the state (Campbell, 1970).

The US Supreme Court, represented by Judge Roger Taney, ruled that if state courts were able to overturn federal judgments on the application of federal laws, the government would lose the ability to enforce federal laws. 
Inevitably, different states would provide their own interpretations of the US Constitution and there would be no unified government established by the Constitution. The power of the Wisconsin courts was limited by the US Constitution, and they could not declare unconstitutional federal acts or reverse decisions of federal courts (United States Supreme Court, 1859).

This decision did not prohibit blacks who legally found themselves in free states from filing claims for freedom, and the federal agents, who formally had the right to demand assistance from local authorities, faced sabotage and even direct violence.

This decision was much more important for the development of American constitutionalism. It created a precedent for the superiority of federal laws over state laws and was a milestone in the formation of the dual court system. In addition, the state's right to nullify was denied by the corresponding decision of the US Supreme Court.

The concept of nullification was initially associated not with judicial practice but rather with disputes over prerogatives of the federal government and the right of states to secession, as well as an economic conflict between the North and the South over customs tariffs (Huston, 2003).

Many southerners regarded tariffs as leverage from the North. As a result, John C. Calhoun, a Senator from South Carolina, announced the right of states to nullify, i.e., a refusal to apply federal laws in their territory. The US Congress had the power to enact federal laws in the interests of all the states, therefore the states could determine whether a particular law was in their best interest. In case of a dispute about the constitutionality of laws, each state could block its operation in its territory or hold a convention to resolve the issue of nullification.

This theory was realized after the adoption of the new tariff in 1832 . The convention in South Carolina nullified both tariffs and enabled local authorities to enforce such nullification. At the initiative of President Andrew Jackson, the US Congress passed a bill empowering the President to use military and navy force to implement acts of the Congress. The Civil War could have started as early as 1832 .

Henry Clay, a Senator from Kentucky, proposed a compromise, according to which tariffs should be gradually reduced from 1833 to 1842 , eventually reaching the level of 1816 . However, both parties could not resist symbolic actions. The US Congress passed the Compromise Bill and the Force Bill on the same day as the South Carolina Convention nullified the Force Bill (Mountjoy, 2009).

However, the 'tight knot' of economic interests and disputes over supremacy was not resolved through tariff changes. The status of territories remained questionable. In the early 1830 s, the US Congress made another 
outrageous decision and banned the sale of federal lands in such territories. Robert Hayne, a Senator from South Carolina, highlighted the need for an alliance between the West and the South against the dictatorship of the North since the latter took advantage of federal laws to restrict labor migration to the West from the New England states, providing themselves with cheap workers.

\section{New territories and new challenges. Kansas on fire and the Dred Scott case}

The economic development of California required the construction of a transcontinental railroad, which promised great financial benefits. There were two promising routes: from Illinois through Kansas and Nebraska in the north, or from Louisiana through Texas and New Mexico in the south. A potential change in the balance of free and slave states in the Senate depended on the solution of this issue if the new territories were given the status of states (Carlisle, 2008).

Stephen Douglas, a Democratic Senator from Illinois, proposed to extend the Compromise Principle of 1850 to Kansas and Nebraska and build a route through these states. The issue of slavery should be resolved by the settlers themselves based on the principle of squatter sovereignty. For slave owners, this meant removing the issue of slavery in the new territories from the jurisdiction of the federal authorities and created prospects for the spread of slavery and the maintenance of balance in the Senate. S. Douglas reassured the Northerners that these states were not suitable for plantation management, therefore the extension of slavery practices would be unlikely. The thing is that both territories were located north of the Missouri Compromise line, i.e. latitude $36^{\circ} 30^{\prime} \mathrm{N}$.

The bill hardly passed the House of Representatives (113 in favor; 100 against) and was signed by President Franklin Pierce in 1854. When the decision was transferred to the territories themselves, it provoked outright violations of the law. In Kansas, clashes turned into real battles (for example, near the village of Lawrence) and more than 200 people were killed (Carlisle, 2008).

The new President J. Buchanan demanded the interim Governor to adopt the state constitution, hoping that the legal consolidation of some principles would end the 'hot phase' of the conflict. Upon the invasion of slavery supporters, a referendum was held which confirmed that all slaves in Kansas preserved their status. After that, the Constitution was passed that allowed slavery in Kansas. Considering numerous violations in the referendum, the US Congress refused to include Kansas in the Union. Even Stephen Douglas, who regarded it as a violation of settler sovereignty, 
opposed the Lecompton Constitution. Kansas was eventually adopted in early 1861 as a free state before the beginning of the Civil War (Mountjoy, 2009).

President J. Buchanan, who came to power during a civil, constitutional and partisan crisis (the conflict between Kansas and Nebraska provoked a split in the Democratic Party and the Whig Party; the creation of a regional Republican Party representing the interests of the North and uniting the northern branches of the Whigs and Democrats, as well as representatives of the American Freedom Party), saw the only solution in the adoption of an unambiguous legal decision that would resolve all the existing contradictions and unite the parties with a binding precedent.

This decision was supposed to be a verdict in the Dred Scott v. Sanford case, one of the most iconic cases in the history of the US Supreme Court known not only by its significance but also as the worst decision in the history of the US Supreme Court (Schwartz, 1997).

In 1854, the dispute about the freedom of the slave Dred Scott (and his daughter who was free by any law since she was born in a free state) and his owner Irene Emerson reached the US Supreme Court, where it had been considered until 1856 (Fehrenbacher, 1997). Indeed, this case had a clear political component. Democrat J. Buchanan, who won the election with considerable efforts, viewed this court decision as the only way to resolve the constitutional crisis that was eroding the entire US state system. The president asked his friend, Supreme Court Justice John Carton, to hear the case before the inauguration. The northerner judges were pressured to make a unanimous decision since a split, especially on a regional basis, could only exacerbate the overall crisis (Baker, 2004).

The ruling by Supreme Court Justice Roger Taney was almost 200 pages long (United States Supreme Court, 1857). R. Taney announced that "the Founding Fathers did not include blacks and did not intend to include them in the category of "US citizens". Consequently, they could not appeal to the rights and privileges listed in the Constitution, as well as to the instruments of their protection, such as the federal court" (Chemerinsky, 2015: 722). According to Taney, blacks, whether slaves or free, and the descendants of former slaves could not sue at all. Furthermore, Taney believed that the Missouri Compromise and all the subsequent compromises were unconstitutional since they limited property rights provided by the Fifth Amendment (Chemerinsky, 2015).

The decision was disastrous. Two Supreme Court Justices recorded dissenting opinions. Justice McLean highlighted that there was no reason and no indication in the text of the Constitution that blacks could not be US citizens. When the Constitution was ratified, blacks had the right to vote in five out of 13 states. Taney's decision was dictated by "prejudice rather than law" (Chemerinsky, 2015: 771). 
Judge Benjamin Curtis mentioned that since Taney had recognized that blacks could not go to federal courts, the rest of judicial decisions became null and void (obitur dicta) and did not create a binding precedent (Chemerinsky, 2015).

\section{Conclusions}

The confrontation over the issue of human rights and the relationship between the federal government and the states only intensified. The northerners feared that Taney would go further and declare all the antislavery laws unconstitutional. The northern press introduced the slavocracy term, denoting a conspiracy of 347,000 slave owners to seize power over a million-strong nation. The southern radicals expressed an opinion that there would be a slave auction on the Boston Stock Exchange in ten years (Mountjoy, 2009).

It was unclear how this precedent correlated with the "squatter sovereignty" (popular sovereignty) defended by slave owners. During the presidential election of 1860, A. Lincoln used this logical contradiction against the Democratic candidate A. Douglas, saying that if Congress could not prohibit slavery in the federal territory, then it would not delegate this power (McClintock, 2008).

Our review has proved that the traditional view on the South (the southerners defended the independence of their states) and the North (the northerners supported the idea of a strong federal government) is not fully justified. In the conditions of a growing constitutional crisis, both parties used federal and local institutions as tools in their confrontation. In this context, courts, Congress, and other entities lost their constitutional significance.

Nevertheless, this confrontation resolved several burning issues about the relationship between the rights of states and the federal government and revealed the extraterritoriality of the US army. In the long run, Taney's disastrous decision resulted in the Civil Rights Act of 1866 and the 14th Amendment of 1868, which became the basis for the legal concept of American citizenship.

By the middle of the $19^{\text {th }}$ century, economic and political interests, gaps in the US Constitution and legal concepts, complex precedents had woven into a knot that could not be cut, as Buchanan wanted, by a purely legal decision. It became clear at 4:30 a.m. on April 12, 1861 when the first shells fell on Fort Sumter. 


\section{Acknowledgments}

The reported study was funded by RFBR, project number 20-01100794 A.

\section{Bibliographic References}

BAKER, Jean H. 2004. James Buchanan: the American Presidents series: the 15th President, 1857-1861. Macmillan. New York, USA.

CAMPBELL, Stanley. 1970. The slave catchers: enforcement of the Fugitive Slave Law, 1850-1860. The University of North Carolina Press. Chapel Hill. NC., USA.

CARLISLE, Rodney P. 2008. Civil war and reconstruction. Infobase Publishing. New York, USA.

CHEMERINSKY, Erwin. 2015. Constitutional law: principles and policies. Wolters Kluwer. New York, USA.

FEHRENBACHER, Don E. 1997. The Dred Scott case: its significance in American law and politics. Oxford University Publishing. Oxford, UK.

GOLDSTEIN, Leslie Friedman. 2011. “A ‘Triumph of freedom' after all? Prigg v. Pennsylvania re-examined” In: Law and History Review. Vol. 29, pp. 763-796.

HURD, John. 1968. Law of freedom and bondage in the United States. Little Brown and Company. Boston, MA.

HUSTON, James L. 2003. Calculating the value of the union: slavery, property rights, and the economic origins of the civil war. The University of North Carolina Press. Chapel Hill, NC., USA.

KACZOROWSKI, Robert J. 1986. "Revolutionary constitutionalism in the era of the civil war and reconstruction" In: New York University Law Review. Vol. 61, pp. 863-940.

KETTNER, James. 1978. The development of American citizenship, 1608-1870. The University of North Carolina Press. Chapel Hill, NC.

LOCKLEY, Fred. 1922. "The case of Robin Holmes vs. Nathaniel Ford” In: The Quarterly of the Oregon Historical Society. Vol. 23, No. 2, pp. 111-137.

MCCLINTOCK, Russell. 2008. Lincoln and the decision for war: the northern response to secession. The University of North Carolina Press. Chapel Hill. NC., USA. 
Roman Romashov, Ekaterina Petrova, Zurab Kalandarishvili y Victor Kovalev

American constitutionalism and the mid-19th-century nation

MOUNTJOY, Shane. 2009. Causes of the civil war: the differences between the North and South. Infopress Publishing. New York, USA.

NADELHAFT, Jerome. 1966. "The Somersett case and slavery: myth, reality, and repercussions" In: Journal of Negro History. Vol. 51, No. 3, pp. 193208.

SCHWARTZ, Bernard. 1997. A book of legal lists: the best and worst in American law. Oxford University Publishing. Oxford, UK.

UNITED STATES SUPREME COURT. 1842. Prigg v. Pennsylvania, 41 U.S. (16 Pet.) 539 (1842). Library of Congress. Available online. In: http:// cdn.loc.gov/service/ll/usrep/usrep041/usrep041539/usrep041539.pdf. Consultation date: 10/12/2020.

UNITED STATES SUPREME COURT. 1857. Dred Scott v. Sandford, 60 U.S. (19 How.) 393 (1857). Library of Congress. Available online. In: http:// cdn.loc.gov/service/ll/usrep/usrepo6o/usrepo60393/usrepo60393. pdf. Consultation date: 10/12/2020.

UNITED STATES SUPREME COURT. 1859. Ableman v. Booth, 62 U.S. (21 How.) 506 (1859). Library of Congress. Available online. In: http://cdn. loc.gov/service/ll/usrep/usrepo62/usrepo62506/usrep062506.pdf. Consultation date: 10/12/2020.

VARON, Elizabeth R. 2008. Disunion: the coming of the American Civil War, 1789-1859. The University of North Carolina Press. Chapel Hill. NC., USA.

WIECEK, William. 1977. The sources of antislavery Constitutionalism in America 1760-1848. Cornell University Press. Ithaca and London. NY, USA. 

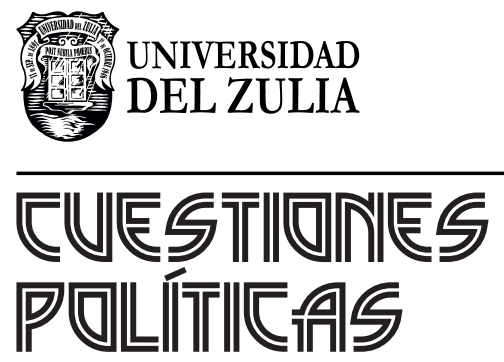

Vol. 39 N $^{\circ} 71$

Esta revista fue editada en formato digital y publicada en diciembre de 2021, por el Fondo Editorial Serbiluz, Universidad del Zulia. Maracaibo-Venezuela 